\title{
Jarak Genetik dan Faktor Peubah Pembeda Entok Jantan dan Betina Melalui Pendekatan Analisis Morfometrik
}

\section{(Genetic Distance and Discriminant Variables on Male and Female of Muscovy duck by Morphometric Analysis)}

\author{
N. Fatmarischa, Sutopo dan S. Johari \\ Fakultas Peternakan dan Pertanian, Universitas Diponegoro, \\ Jl. Prof Sudarto, Semarang 50275, Indonesia \\ e-mail : novemia.f@gmail.com \\ (Diterima: 30 November 2013; Disetujui: 07 Februari 2014)
}

\begin{abstract}
ABSTRAK
Penelitian bertujuan untuk mengetahui jarak genetik, pohon fenogram dan variabel pembeda pada entok jantan dan betina dengan menggunakan analisis diskriminan dan kanonikal. Sampel yang digunakan dalam penelitian berasal dari tiga kabupaten yaitu Kabupaten Pekalongan, Demak, dan Magelang, Provinsi Jawa Tengah. Jumlah sampel entok yang digunakan sebanyak 35 ekor entok jantan dan 35 ekor betina pada tiap kabupaten. Pengamatan terhadap karakter bobot badan, panjang badan, panjang paruh, panjang leher, lingkar badan, panjang sayap, panjang femur, dan panjang jari kaki ketiga. Data yang diperoleh dianalisis menggunakan analisis diskriminan dengan bantuan program SAS. Hasil peta penyebaran menunjukkan adanya perbedaaan entok jantan dan betina. Analisis diskriminan menunjukkan bahwa variabel pembeda entok jantan terdapat pada lingkar badan $(0,85)$ dan panjang leher $(0,66)$, sedangkan entok betina terdapat pada panjang femur $(0,68)$ dan panjang paruh $(0,82)$. Tingkat kesamaan tertinggi antara entok jantan dan betina ditunjukkan pada entok Kabupaten Pekalongan $(97,14)$ dan Magelang $(82,86 \%)$. Jarak genetik pada entok jantan dan betina menunjukkan adanya hubungan kekerabatan antara entok di Kabupaten Magelang dan Pekalongan, serta memiliki hubungan kekerabatan yang jauh dengan entok Demak.
\end{abstract}

Kata kunci : jarak genetik, analisis diskriminan, entok dan morfometrik

\section{ABSTRACT}

Discriminant and canonical analysis on morphometric was used to estimate genetic distance, phylogenetic tree, and discriminant variables of muscovy duck. The material of this study were obtained from three regency namely Pekalongan, Demak, and Magelang, Central Java Province. Thirty five males and 35 females of muscovy were taken as the sample of each regency. Variables observed were body weight, body length, bill length, neck length, breast circumference, wing length, femur length, and length of third toe. Data were analyzed with discriminant analysis using SAS program. Results showed differences from distribution mapping between male and female of muscovy. The discriminant variables of male muscovy measurement existed on breast circumference (0.85) and neck length (0.66), meanwhile for female muscovy on femur length (0.68) and bill length (0.82). The highest similarity between male and female muscovy was obtained from Pekalongan (97.14\%) and Magelang (82.86\%). The genetic closeness of male and female muscovy was shown between Magelang and Pekalongan, while Demak muscovy had a much different character.

Keywords : muscovy duck, genetic distance, morphometric 


\section{PENDAHULUAN}

Entok merupakan salah satu jenis unggas yang memiliki bobot badan yang cukup tinggi yang diharapkan mampu membantu dalam pemenuhan kebutuhan protein hewani. Entok memiliki penyebaran yang cukup luas di Indonesia. Entok jantan memiliki rerata bobot badan $3 \mathrm{~kg} /$ ekor sedangkan betina 1,3 kg/ekor. Kelebihan dari entok yaitu lebih tahan terhadap penyakit dan merupakan jenis unggas sebagai penghasil daging (Johnson and Hawk, 2009; Petty, 2011).

Penelitian mengenai analisis ukuran tubuh entok belum banyak dilakukan di Indonesia. Analisis yang dapat digunakan untuk mengetahui karakteristik ukuran tubuh entok yaitu melalui analisis diskriminan dan jarak genetik. Jarak genetik adalah tingkat perbedaan gen (perbedaan genomik) pada suatu populasi atau spesies yang diukur melalui kuantitas numerik (Nei, 1987), sedangkan analisis diskriminan dapat diketahui melalui jarak Mahalanobis. Hasil jarak genetik digunakan untuk mengetahui pohon filogenetik. Pohon filogenetik merupakan diagram cabang yang menggambarkan suatu susunan hubungan kekerabatan pada suatu populasi atau kelompok tertentu dan dengan menggunakan metode UPGMA (Unweighted Pair Group Method With Arithmetic) (Wiley, 1981; Nei, 1987).

Penelitian yang dilakukan bertujuan untuk menentukan jarak genetik, pohon filogenetik, dan faktor pembeda entok di tiga kabupaten berbeda. Hasil penelitian diharapkan mampu memberikan informasi dasar bagi program pemuliaan entok.

\section{MATERI DAN METODE}

\section{Lokasi penelitian}

Data mengenai ukuran tubuh diambil di tiga lokasi penelitian yaitu Kabupaten Pekalongan, Demak, dan Magelang di Provinsi Jawa Tengah. Penentuan lokasi pengambilan sampel menggunakan metode purposive sampling.

\section{Materi penelitian}

Entok yang digunakan dalam penelitian sebanyak 210 ekor yang diamati di beberapa peternak tradisional yang terdiri dari 35 ekor entok jantan dan 35 ekor entok betina di Kabupaten Pekalongan, 35 ekor entok jantan dan 35 ekor entok betina di Kabupaten Demak, serta 35 ekor entok jantan dan 35 ekor entok betina di Kabupaten Magelang. Variabel pengukuran tubuh yang diamati meliputi bobot badan, panjang badan, panjang paruh, panjang leher, lingkar badan, panjang sayap, panjang femur, panjang jari kaki ke-3. Daerah penelitian digunakan sebagai peubah pembeda antar entok.

\section{Analisis data}

Pendekatan jarak Mahalanobis dengan matriks peragam antara peubah berdasarkan lokasi penelitian (pooled) disusun menjadi sebuah matriks yang digunakan untuk mengetahui fungsi diskriminan. Hasil penggabungan dapat dijelaskan dalam bentuk matriks:

$$
\mathrm{C}=\left[\begin{array}{cccc}
\mathrm{C}_{11} & \mathrm{C}_{12} & \ldots & \mathrm{C}_{1 p} \\
\mathrm{C}_{21} & \mathrm{C}_{22} & \ldots & \mathrm{C}_{2 \mathrm{p}} \\
\ldots & \ldots & \ldots & \ldots \\
\mathrm{C}_{\mathrm{p} 1} & \mathrm{C}_{\mathrm{p} 2} & \ldots & \mathrm{C}_{\mathrm{PP}}
\end{array}\right]
$$

Jarak genetik minimum menurut Nei (1987) dihitung menggunakan rumus:

$$
\mathrm{D}^{2}{ }_{(\mathrm{i} j \mathrm{j})}=\left(\overline{\mathrm{X}}_{\mathrm{i}}-\overline{\mathrm{X}}_{\mathrm{j}}\right) \mathrm{C}^{-1}\left(\overline{\mathrm{X}}_{\mathrm{i}}-\overline{\mathrm{X}}_{\mathrm{j}}\right)
$$

$\mathrm{D}^{2}{ }_{(\mathrm{i} j)}=$ nilai statistik Mahalanobis sebagai ukuran jarak kuadrat genetik antar dua lokasi (antara lokasi i terhadap lokasi j)

$\mathrm{C}^{-1}=$ kebalikan matriks gabungan ragam peragam antar peubah

$\overline{\mathrm{X}}_{\overline{\mathrm{i}}}=$ vektor nilai rataan pengamatan dari lokasi entok i pada masingmasing peubah

$\overline{\mathrm{X}}_{\mathrm{j}} \quad=$ vektor nilai rataan pengamatan dari lokasi entok $\mathrm{j}$ pada masingmasing peubah

Analisis data menggunakan program bantu SAS yang terdiri dari Proc Candisc digunakan untuk menentukan variabel pembeda entok dan penentuan peta penyebaran pada lokasi yang berbeda. Proc Discrim digunakan untuk mengetahui persentase kesamaan dan jarak genetik entok pada lokasi yang berbeda. 
Proc Stepdisc digunakan untuk mengetahui fungsi linear bertingkat (stepwise) untuk menegaskan hasil analisis diskriminan (SAS, 1990). Hasil analisis diskriminan digunakan untuk menentukan jarak genetik yang akan membentuk pohon filogenetik dengan menggunakan program MEGA 5 melalui metode UPGMA (Unweighted Pair Group Method with Arithmetic) (Tamura et al., 2011).

\section{HASIL DAN PEMBAHASAN}

\section{Penyebaran entok jantan dan betina di tiga lokasi}

Hasil analisis kanonikal menunjukkan bahwa berdasarkan ukuran tubuh, penyebaran entok jantan di kabupaten Demak terlihat paling luas dibandingkan Magelang dan Pekalongan (Gambar 1), sedangkan penyebaran entok betina terlihat lebih merata (Gambar 2). Gambar 1 menunjukkan bahwa entok Kabupaten Pekalongan berkumpul disebelah kiri axis Y dan entok Demak banyak menyebar di sebelah kanan axis Y. Entok Magelang menyebar pada daerah atas axis X. Pada Gambar 2 menunjukkan hasil berbeda dengan Gambar 1 yaitu entok Kabupaten Demak menyebar di sebelah kiri axis Y sedangkan entok Magelang dan Pekalongan banyak

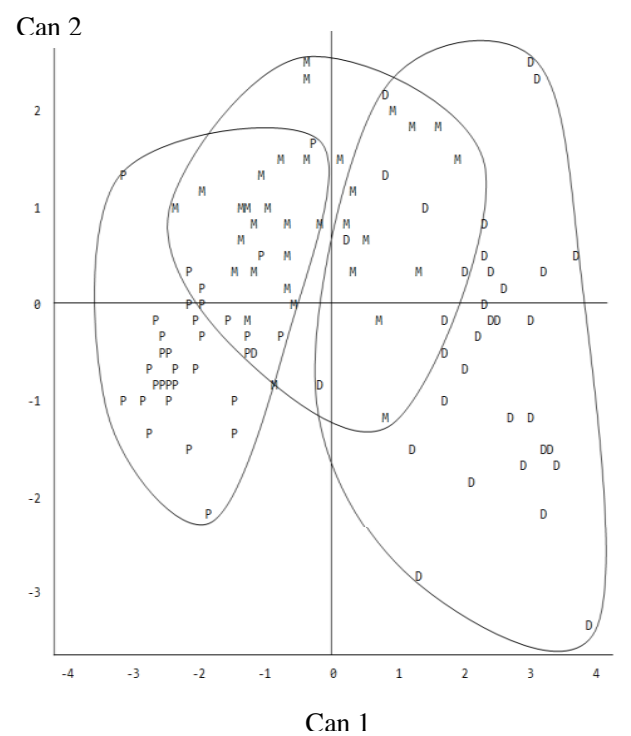

Gambar 1. Peta penyebaran entok jantan di tiga kabupaten berbeda. $\mathrm{P}=$ entok pekalongan, $\mathrm{M}=$ entok magelang, $\mathrm{D}=$ entok demak menyebar pada daerah kanan axis $\mathrm{Y}$.

Entok jantan dan betina di Kabupaten Magelang dan Pekalongan (Gambar 1 dan 2) memiliki hubungan yang relatif berdekatan secara morfologi karena menunjukkan adanya himpitan entok Magelang yang dalam pada entok Pekalongan. Tingkat himpitan antar kelompok menurut Utomo et al. (2010) menunjukkan tingkat kesamaan fenotipik yang dilihat melalui ukuran tubuh. Penelitian Taylor et al. (1977) pada Brahmantiyo et al. (2011) bahwa jarak yang membagi sutau wilayah dipengaruhi oleh karakteristik sifat ukuran tubuh suatu populasi dalam satu wilayah. Adanya perbedaan hubungan kekerabatan yang dihasilkan karena adanya respon genetik masing-masing entok pada lokasi yang berbeda.

Perbedaan respon genetik antara jantan dan betina pada lokasi berbeda juga dipengaruhi oleh kondisi fisiologis masing-masing entok. Mulder dan Bijma (2005) melaporkan bahwa dalam pemuliaan ternak, untuk memperbaiki performan ternak dengan melalui seleksi genetik tidak hanya dipengaruhi oleh genetik ternak tersebut tetapi juga dipengaruhi oleh lingkungan.

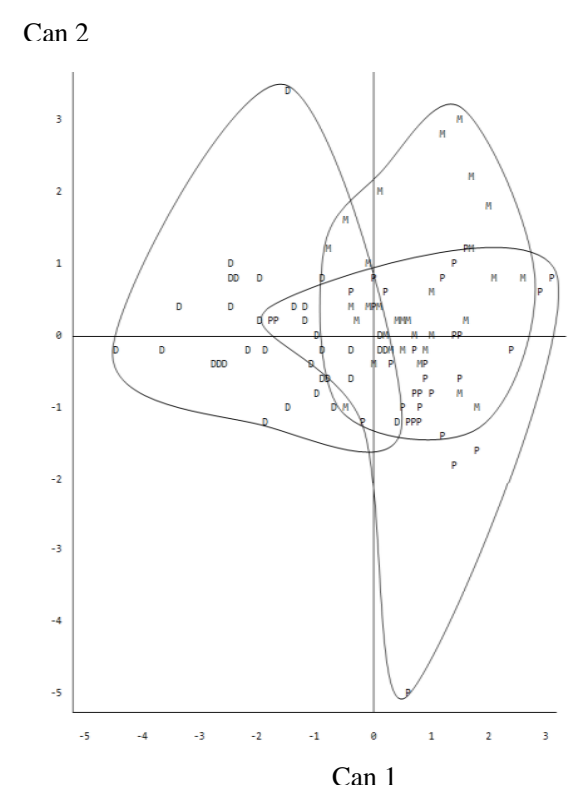

Gambar 2. Peta penyebaran entok betina di tiga kabupaten berbeda. Keterangan $\mathrm{P}=$ entok pekalongan, $\mathrm{M}=$ entok magelang, $\mathrm{D}=$ entok demak 
Tabel 1. Hasil analisis canonical

\begin{tabular}{lcccc}
\hline \multirow{2}{*}{ Variabel } & \multicolumn{2}{c}{ Canonical 1} & \multicolumn{2}{c}{ Canonical 2 } \\
\cline { 2 - 5 } & Jantan & Betina & Jantan & Betina \\
\hline Bobot badan & 0,32 & $-0,06$ & $-0,03$ & $-0,13$ \\
Panjang badan & 0,15 & $-0,17$ & 0,50 & 0,24 \\
Panjang paruh & $-0,41$ & 0,30 & $-0,11$ & 0,82 \\
Panjang leher & 0,12 & 0,70 & 0,66 & 0,23 \\
Lingkar badan & 0,85 & $-0,59$ & $-0,37$ & 0,27 \\
Panjang sayap & 0,07 & 0,40 & 0,21 & 0,49 \\
Panjang femur & $-0,76$ & 0,68 & $-0,03$ & 0,08 \\
Panjang kaki ke-3 & $-0,53$ & 0,41 & $-0,25$ & 0,42 \\
\hline
\end{tabular}

\section{Analisis kanonikal entok jantan dan betina di tiga lokasi}

Hasil analisis kanonik digunakan untuk menentukan faktor pembeda pada entok di lokasi pemeliharaan yang berbeda. Ogah (2013) melaporkan bahwa analisis diskriminan kanonikal merupakan analisis multivariat untuk mengetahui hubungan kekerabatan antara dua atau lebih variabel. Peubah ukuran tubuh entok jantan pada variabel lingkar badan $(0,85)$ dan panjang leher $(0,66)$ dapat digunakan sebagai pembeda entok di tiga kabupaten karena menunjukkan nilai positif yang tinggi (Tabel 1). Pada entok betina, variabel panjang femur $(0,68)$ dan panjang paruh $(0,82)$ menunjukkan nilai positif yang tinggi. Perbedaan variabel peubah pembeda pada entok jantan dan betina dapat dipengaruhi oleh hormon. Baeza et al. (2001) menyatakan bahwa jenis kelamin mempengaruhi hormon yang bekerja pada pertumbuhan.

Variabel dengan nilai positif yang tinggi dapat diindikasikan sebagai variabel pembeda pada ukuran tubuh, sedangkan hasil yang bernilai negatif diindikasikan kurang dapat digunakan sebagai variabel pembeda pada entok yang diamati. Persamaan hasil analisis komponen utama antara ternak jantan dan betina di tiga kabupaten berbeda menunjukkan bahwa variabel pembeda antar jenis kelamin yang dilihat melalui ukuran-ukuran tubuh dapat dijadikan pembeda antar daerah. Muzani et al. (2005) melaporkan bahwa semakin rendah hasil dari analisis canonical, maka tidak dapat digunakan sebagai peubah pembeda.
Hasil analisis diskriminan stepwise (Tabel 2) menunjukkan bahwa lingkar badan, panjang kaki ke-3, panjang badan, panjang femur, dan panjang leher memberikan pengaruh $(\mathrm{P}<0,0001)$ yang besar terhadap ukuran tubuh entok jantan. Pada entok betina, variabel panjang leher, lingkar badan, panjang femur, panjang paruh, dan bobot badan menunjukkan pengaruh yang besar di kabupaten berbeda. Hal ini sependapat dengan Yakubu dan Ugbo (2011) bahwa panjang kaki, panjang leher, panjang badan menunjukkan nilai yang besar pada analisis stepwise.

Pada analisis stepwise didapatkan bahwa terdapat 5 variabel pada masing-masing jenis kelamin yang diperkirakan memberikan pengaruh pada penyusunan jarak Mahalanobis.

Tabel 2. Hasil analisis stepwise sebagai peubah pembeda

\begin{tabular}{ccc}
\hline Variabel & $\begin{array}{c}\text { Wilks' Lamda } \\
(\lambda)\end{array}$ & $\begin{array}{c}\text { Rerata korelasi } \\
\text { canonical }\end{array}$ \\
\hline Jantan Lingkar badan & 0,41764515 & 0,29117743 \\
Panjang kaki ke-3 & 0,27400787 & 0,37946594 \\
Panjang badan & 0,24330745 & 0,43024136 \\
Panjang femur & 0,20965506 & 0,45642334 \\
Panjang leher & 0,18383874 & 0,49844083 \\
Betina Panjang leher & 0,71814639 & 0,14092680 \\
Lingkar badan & 0,55499662 & 0,22601555 \\
Panjang femur & 0,47212993 & 0,26813025 \\
Panjang paruh & 0,43696725 & 0,30444064 \\
Bobot badan & 0,40905819 & 0,32352932 \\
\hline
\end{tabular}

Nilai kesamaan entok jantan dan betina di tiga kabupaten

Berdasarkan analisis diskriminan (Tabel 3) dapat diketahui bahwa pada entok jantan di Kabupaten Pekalongan tidak memiliki campuran $(0,0 \%)$ dengan entok Demak, 
Tabel 3. Tingkat kesamaan entok di tiga kabupaten berbeda

\begin{tabular}{llrrrc}
\hline & Kabupaten & Demak & Magelang & Pekalongan & Total \\
\hline \multirow{2}{*}{ Jantan } & Demak & 82,86 & 11,43 & 5,71 & 100,00 \\
& Magelang & 8,57 & 54,29 & 37,14 & 100,00 \\
& Pekalongan & 0,00 & 2,86 & 97,14 & 100,00 \\
Betina & Demak & 57,14 & 37,14 & 5,71 & 100,00 \\
& Magelang & 0,00 & 82,86 & 17,14 & 100,00 \\
& Pekalongan & 5,71 & 42,86 & 51,43 & 100,00 \\
\hline
\end{tabular}

Tabel 4. Jarak genetik entok jantan di tiga kabupaten berbeda

\begin{tabular}{lllc}
\hline Kabupaten & Demak & Magelang & Pekalongan \\
\hline Demak & 0,00000 & 7,63929 & 18,71662 \\
Magelang & 7,63929 & 0,00000 & 4,96207 \\
Pekalongan & 18,71662 & 4,96207 & 0,00000 \\
\hline
\end{tabular}

Tabel 5. Jarak genetik entok betina di tiga kabupaten berbeda

\begin{tabular}{llcc}
\hline Kabupaten & Demak & Magelang & Pekalongan \\
\hline Demak & 0,00000 & 5,34381 & 5,92635 \\
Magelang & 5,34381 & 0,00000 & 0,78218 \\
Pekalongan & 5,92635 & 0,78218 & 0,00000 \\
\hline
\end{tabular}

sedangkan entok Demak dan Magelang menunjukkan hasil memiliki campuran dari daerah lain. Entok betina di Kabupaten Magelang tidak memiliki campuran dengan entok Demak $(0,00 \%)$.

Pada entok jantan, kesamaan ukuran tubuh dengan nilai rendah pada wilayah yang sama ditunjukkan pada entok Magelang $(54,29 \%)$ dibandingkan dengan entok daerah lain. Kesamaan terendah pada entok betina ditunjukkan oleh entok Pekalongan sebesar $51,43 \%$. Sementara itu, nilai kesamaan tertinggi pada entok jantan dan betina ditunjukkan pada entok Pekalongan dan Magelang sebesar $97,14 \%$ dan $82,86 \%$. Nilai kesamaan yang tinggi menunjukkan besarnya keseragaman yang terjadi pada entok jantan ataupun betina yang dilihat melalui ukuran tubuh entok. Muzani et al. (2005) melaporkan bahwa hasil analisis diskriminan dapat digunakan untuk menduga adanya nilai kesamaan dalam suatu kelompok/bangsa. Lebih lanjut Brahmantiyo et al. (2003) menyatakan adanya persamaan secara fenotipik pada jenis-jenis itik dikarenakan pengaruh genetik, lingkungan dan mutasi.

\section{Jarak genetik entok jantan dan betina di tiga kabupaten}

Jarak genetik merupakan tingkat perbedaan gen (perbedaan genomik) suatu populasi atau spesies yang diukur melalui kuantitas numerik (Nei, 1987). Pendugaan jarak genetik melalui ukuran tubuh dapat dilakukan sebagai indikasi awal dalam penentuan hubungan kekerabatan entok di tiga kabupaten berbeda. Nilai matrik Mahalanobis entok jantan dan betina ditunjukkan pada Tabel 4 dan 5 serta hasil pohon filogenetik berdasarkan matrik Mahalanobis ditampilkan pada Gambar 3 dan 4. Pohon filogenetik menggambarkan jarak genetik secara keseluruhan lokasi pengamatan entok. Hasil jarak genetik berdasarkan ukuran-ukuran tubuh menunjukkan bahwa entok Magelang memiliki kedekatan dengan entok Pekalongan dan memiliki jarak yang cukup jauh dengan entok Demak. Pohon filogenetik menunjukkan bahwa tidak ada perbedaan antara entok jantan dan betina di tiga kabupaten berbeda. Jarak genetik tertinggi ditunjukkan pada entok jantan karena memiliki angka kesamaan yang jauh dibandingkan dengan entok betina dari tiga kabupaten berbeda. El-Gendy et al. (2005) melaporkan bahwa hubungan kekerabatan yang berdekatan dapat dikarenakan adanya komposisi genetik yang spesifik dengan interaksi pada kondisi lingkungan.

\section{KESIMPULAN}

Jarak genetik yang dilihat melalui Mahalanobis menunjukkan entok jantan dan 


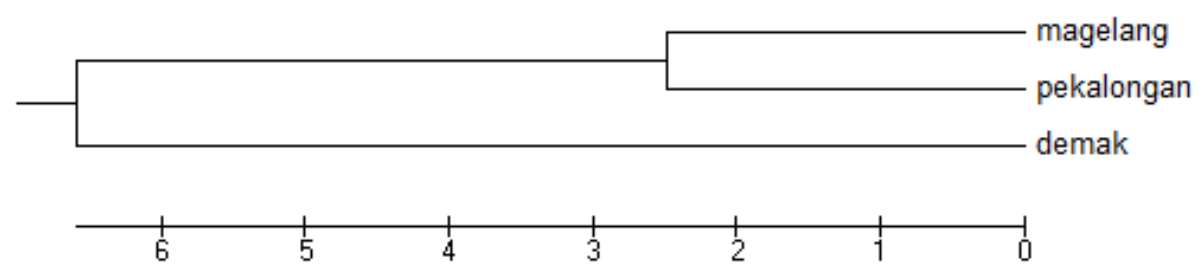

Gambar 3. Pohon filogenetik entok jantan di tiga kabupaten berbeda

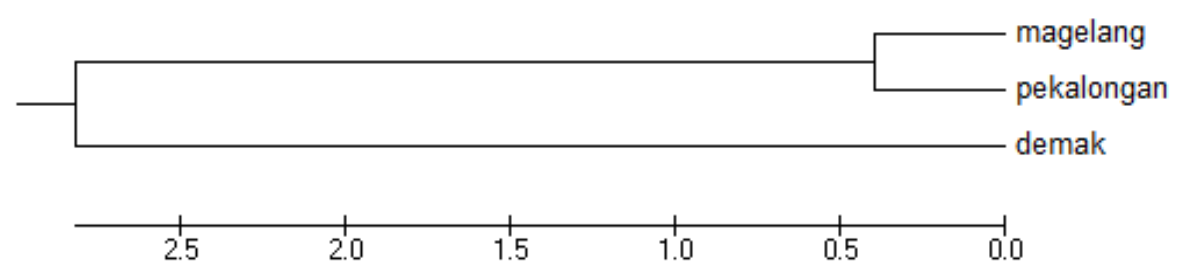

Gambar 4. Pohon filogenetik entok betina di tiga kabupaten berbeda

betina memiliki hasil yang sama yaitu entok Kabupaten Magelang memiliki hubungan kekerabatan yang dekat dengan entok Pekalongan dan berjauhan dengan entok Demak. Peubah yang dapat digunakan sebagai pembeda entok antar kabupaten yaitu lingkar badan, panjang kaki ke-3, panjang badan, panjang femur, dan panjang leher pada entok jantan sedangkan panjang leher, lingkar badan, panjang femur, panjang paruh, dan bobot badan pada entok betina. Peubah pembeda dapt dilihat pada pola penyebaran yang terlihat berbeda antara entok jantan dan betina.

\section{DAFTAR PUSTAKA}

Baeza, E., J. Williams, D. Guemene, and M. J. Duclos. 2001. Sexual dimorphism for growth in Muscovy ducks and changes in insulin-like growth factor I (IGF-I), growth hormone $(\mathrm{GH})$ and triiodothyronine (T3) plasma levels. Reprod. Nutr. Dev. 41: 173-179.

Brahmantiyo, B., L. H. Prasetyo, A. R. Setioko, dan R. H. Mulyono. 2003. Pendugaan jarak genetik dan faktor peubah galur itik (Alabio, Bali, Khaki, Campbell, Mojosari dan Pegagan) melalui analisis morfometrik. JITV 8 (1): 1-7.
Brahmantiyo, B., T. Sartika, dan S. Sopiyana. 2011. Pendugaan jarak genetik ayam merawang (studi kasus di BPTU sapi dwiguna dan ayam, Sembawa dan Pulau Bangka, Sumatera Selatan). Balai Penelitian Ternak. Seminar Nasional Teknologi Peternakan dan Veteriner. Hal 632-640.

El-Gendy, E. A., M. A. Helal, N. H. Goher, and A. Mostageer. 2005. Molecular characterization og genetic biodiversity in ducks, using RAPD-PCR analysis. Arab J. Biotech. 8 (2): 253-264.

Johnson, S. A. and M. Hawk. 2009. Florida's Introduced Birds: Muscovy Duck (Cairina moschata). Department of Wildlife Ecology and Conservation, University of Florida/IFAS, Florida.

Mulder, H. A and P. Bijma. 2005. Effects of genotype by environment interaction on genetic gain in breeding prgrams. J. Anim. Sci. 83: 49-61.

Muzani, A., B. Brahmantiyo, C. Sumantri, dan A. Tapyadi. 2005. Pendugaan jarak genetik pada itik Cihateup, Cirebon dan Mojosari. Med. Pet. 23 (3): 109-116.

Nei. M. 1987. Molecular Evolutionary Genetics. Colombia University Press, New York. 
Ogah, D. M. 2013. Canonical discriminant analysis of morphometric traits in indigenous chicken genotypes. Trakia J. of Sci. 2 (11): 170-174.

Petty, C. 2011. Cairina moschata (Wild Muscovy duck). The Online Guide to the Animals of Trinidad and Tobago.

SAS. 1990. SAS/STAT Users Guide Version 6. Fourth Edition. Volume 2. SAS Campus Drive. Cary. North Carolina 27513, USA.

Tamura K., D. Peterson, N. Peterson, G. Stecher, M. Nei, and S. Kumar. 2011. MEGA5: Molecular evolutionary genetics analysis using maximum likelihood, evolutionary distance, and maximum Parsimony Methods. Molecular Biology and Evolution.
Arizona State University. Arizona. USA.

Utomo, B. N., R. R. Noor, C. Sumantri, I. Supriatna, dan E. D. Gunardi. 2010. Keragaman morfometrik sapi katingan di Kalimantan Tengah. JITV 15 (3): 220-230.

Wiley, E. O. 1981. Phylogenetics : The Theory and Practice of Phylogenetics Systematics. University of Kansas, Lawrence. John Wiley and Son. New York.

Yakubu and S. B. Ugbo. 2011. An assessment of biodiversity in morphological traits of Muscovy ducks in Nigeria using discriminant analysis. International Proceedings of Chemical, Biological and Environmental Engineering 1: 389391. 